Nurhaeni Sanda : Efektivitas Penggunaan Pupuk Organik Kascing dan Pupuk Organik Cair pada Pertumbuhan dan Produksi Tanaman Tomat (Lycopersicum esculantum Mill)

\title{
EFEKTIVITAS PENGGUNAAN PUPUK ORGANIK KASCING DAN PUPUK ORGANIK CAIR PADA PERTUMBUHAN DAN PRODUKSI TANAMAN TOMAT (Lycopersicum esculantum Mill)
}

\section{(Effectiveness of Using Organic Fertilizer Kascing and Liquid Organic Fertilizer on Growth and Production of Tomato Plant (Lycopersicum esculantum Mill))}

\author{
Nurhaeni Sanda ${ }^{1}$, Netty Syam ${ }^{2}$ \\ ${ }^{1)}$ Pascasarjana Universitas Muslim Indonesia Makassar \\ nurhaeni_sanda@yahoo.com \\ ${ }^{2)}$ Fakultas Pertanian Universitas Muslim Indonesia \\ netty.said@umi.ac.id
}

\begin{abstract}
This research aims to 1) get the best effect of organic kascing fertilizer on growth and production of tomato plants. 2) Getting the best concentration of Lestari Green liquid organic fertilizer on growth and production of tomato plants. 3) Obtain a combination of organic kascing fertilizer dosage and concentration of liquid organic fertilizer Lestari Green on growth and production of tomato plants. This research was conducted from January to April 2017 in Sudiang Biringkanaya district., Makassar City, South Sulawesi, design with a two factor randomized block design was observed, the dose of kascing fertilizer consisted of 4 levels: control, 0.5 tons/ha, 7.5 tons /ha and 10.0 tons/ha. The liquid organic fertilizer factor consists of 4 levels: Control, $5.0 \mathrm{cc} / \mathrm{L}, 10.0 \mathrm{cc} / \mathrm{L}, 15.0 \mathrm{cc} / \mathrm{L}$. The results showed that 1) The use of Kascing organic fertilizer with a dose of 10.0 tons/ha gives the best effect of average height of plants that is $46.04 \mathrm{~cm}$, the fastest flowering age of 31.14 days, productive branches as much as 2.30, the highest number of fruits is 28.28 per plant (11.11 ton/ha; 2) The use of Lestari Green liquid organic fertilizer with concentration of $15 \mathrm{cc} / \mathrm{L}$ gives the best influence on the average of good plant height that is $43.01 \mathrm{~cm}$, the fastest flowering age of 31.69 day, productive branch as much as 2.23, fruit weight as much as $1.65 \mathrm{~kg}$ of crop, weight of fruit per plot of $6.03 \mathrm{~kg}$ (41.86 tons/hectare; 3) Combination of organic fertilizer treatment of kascing and liquid organic fertilizer Lestari Green which can improve growth and increase the production of tomato plants is the treatment of organic fertilizer kascing 10 tons / hectare and concentration p liquid organic fertilizer Lestari Green $15 \mathrm{cc} / \mathrm{L}$ water on parameter Number of leaves and number of fruit.
\end{abstract}

Keywords: Kascing fertilizer, liquid organic fertilizer, tomato plant.

\section{PENDAHULUAN}

Tanaman tomat (Lycopercum Berdasarkan data Direktorat Jenderal esculantum Mill) merupakan salah satu Hortikultura, pada tahun 2014 di komoditas pertanian yang bernilai Indonesia luas panen tomat adalah 56.042 ekonomi tinggi dan banyak diusahakan ha, produksi 887.556 ton dengan secara komersial di Indonesia. Tomat produktivitas 14,84 ton. Sedangkan di dapat dijadikan sayuran, minuman, bahan provinsi Sulawesi Selatan, pada tahun obat-obatan maupun bahan untuk 2015 luas lahan tomat mencapai 3.551 ha, kosmetik (Simamora, 2009). $\quad$ produksi 42.556 ton dengan produktivitas 
8,21 ton. Pada tahun yang sama kebutuhan tomat di dalam negeri mencapai 820.567 ton sehingga Indonesia masih harus mengimpor tomat sebesar 8.857 ton untuk memenuhi kebutuhan tersebut (BPS , 2012).

Fenomena dampak negatif intensifikasi pertanian terhadap pertanian terhadap ekosistem pertanian terjadi karena intensitas pemakaian pupuk kimia yang terus meningkat dari waktu ke waktu. Penggunaan pupuk anorganik selalu diikuti dengan masalah lingkungan berupa kesuburan biologis, kondisi fisik tanah dan berdampak pada konsumen.

Akhir-akhir ini terjadi peningkatan konsumen yang menghendaki produk pertanian yang bebas residu pestisida dan pupuk buatan agar produk tersebut aman dikonsumsi dan terciptanya lingkungan hidup yang sehat. Untuk itu,sistem pertanian organik pemanfaatan pupuk organik untuk membantu penyediaan hara bagi tanaman sangat penting.

Kascing adalah pupuk organik yang berasal dari kotoran atau feces cacing tanah. Pemberian kascing pada tanah dapat memperbaiki sifat tanah seperti memperbaiki struktur, porositas, permeabilitas, meningkatkan kemampuan untuk menahan air. Di samping itu kascing dapat memperbaiki sifat kimia tanah seperti meningkatkan kemampuan untuk menyerap kation sebagai sumber hara makro dan mikro serta meningkatkan pH pada tanah asam. Pemakaian kascing diharapkan mampu mengurangi penggunaan pupuk kimia dan meningkatkan penggunaan pupuk organik sehingga mengurangi pencemaran lingkungan (Luh, 2005).

Kascing juga dapat memperbaiki sifat biologi tanah karena kascing mengandung banyak mikroba dan hormon perangsang pertumbuhan tanaman, seperti giberelin $2.75 \%$, sitokinin $1.05 \%$ dan auksin. Jumlah mikroba yang banyak dan aktivitasnya yang tinggi bisa mempercepat mineralisasi atau pelepasan unsur hara dari kotoran cacing menjadi bentuk yang tersedia bagi tanaman (Mulat, 2003).

Kascing mengandung unsur hara makro dan mikro. Kascing biasanya mengandung nitrogen $(\mathrm{N}) 0.63 \%$, fosfor (P) $0.35 \%$, kalium (K) $0.2 \%$, kalsium $(\mathrm{Ca})$ $0.23 \%$, mangan $(\mathrm{Mn}) 0.003 \%$, magnesium (Mg) $0.26 \%$, tembaga $(\mathrm{Cu}) 17,58 \%$, seng (Zn) $0.007 \%$, besi $(\mathrm{Fe}) \quad 0.79 \%$, molibdenum (Mo) $14.48 \%$, bahan organik $0.21 \%$, KTK $35.80 \%$, kapasitas menyimpan air $41.23 \%$ dan asam humat $13.88 \%$ (Mulat, 2003). 
Selain pupuk Kascing, terdapat juga pupuk organik yang berwujud cair. Pupuk organik cair (POC) merupakan pupuk organik yang berbentuk cairan dan larutan yang mengandung unsur hara tertentu yang bermanfaat bagi pertumbuhan tanaman. Bahan baku pupuk cair dapat berasal dari berbagai macam bahan organik seperti POC Lestari Green.

Pupuk organik cair mampu menyediakan hara secara cepat (Musnamar, 2005), tidak terjadi penumpukan konsentrasi pupuk di satu tempat karena pupuk organik cair larut $100 \%$, sehingga secara cepat mengatasi defesiensi hara. Hanolo, (1997) menyatakan pemberian pupuk organik cair harus memperhatikan konsentrasi yang diaplikaikan terhadap tanaman yang dibudidayakan. Penggunaan konsentrasi pupuk organik cair yang tepat dapat memperbaiki pertumbuhan, mempercepat panen, memperpanjang masa atau umur produksi dan dapat meningkatkan hasil tanaman (Rizqiani,et,al. 2007).

Menurut Rosmarkam dan Yuwono (2006), pemupukan melalui daun memberikan pengaruh yang lebih cepat terhadap tanaman dibanding lewat akar. Kecepatan penyerapan hara juga dipengaruhi oleh status hara dalam tanah.
Bila kadar hara dalam tanah rendah maka penyerapan unsur hara melalui daun relatif lebih cepat dan sebaliknya. Mengingat kandungan unsur hara makro dan mikro dari pupuk organik cair merupakan unsur-unsur hara esensial yang sangat dibutuhkan oleh tanaman, maka dipandang sangat penting untuk dilakukan penelitian untuk menguji dosis pupuk organik cair dengan berbagai tingkat perlakuan untuk meningkatkan pertumbuhan dan hasil tanaman tomat.

\section{METODE PENELITIAN}

Penelitian ini dilaksanakan di Kelurahan Sudiang, Kecamatan Biringkanaya, Kota Makassar yang berlangsung Januari - April 2017.

Penelitian ini dilaksanakan dalam bentuk percobaan, menggunakan Rancangan Acak Kelompok (RAK) dengan 2 faktor. Faktor pertama adalah takaran pupuk kascing 4 taraf takaran yaitu: 5,0 ton/ha $(0,750 \mathrm{~kg} /$ petak $) ; 7,5$ ton/ha $(1,125 \mathrm{~kg} /$ petak $) ; 10,0$ ton/ha $(1,500 \mathrm{~kg} /$ petak $)$ dan tanpa Kascing (Kontrol). Faktor kedua yaitu penggunaan pupuk cair (POC) Lastari Green 4 taraf yaitu: 5,0 cc/L; 10,0 cc/L; 15,0 cc/L dan tanpa POC (kontrol). 

Percobaan ini terdapat 16 unit Untuk melihat pengaruh perlakuan kombinasi perlakuan dan masing-masing dilakukan analisis sidik ragam (Anova) perlakuan diulang tiga kali sehingga dan untuk melihat pengaruh antar diperlukan 48 petak percobaan. Setiap perlakuan dilakukan analisis BNJ $\alpha 0,05$. petak perlakuan terdiri atas 6 tanaman.

\section{HASIL DAN PEMBAHASAN}

\section{Tinggi Tanaman}

Tabel 1. Rata-rata tinggi tanamantomat umur 49 HST

\begin{tabular}{|c|c|c|c|c|c|c|}
\hline \multirow{2}{*}{$\begin{array}{c}\text { Pupuk } \\
\text { Kascing (ton) }\end{array}$} & \multicolumn{4}{|c|}{ POC Lestari Green (cc/L) } & \multirow{2}{*}{ Rata-rata } & \multirow{2}{*}{$\begin{array}{c}\text { NP BNJ } \\
0.05\end{array}$} \\
\hline & 0 & 5 & 10 & 15 & & \\
\hline 0 & 34.78 & 36.96 & 37.31 & 38.70 & $36.94^{\mathrm{d}}$ & \\
\hline 5 & 39.22 & 40.65 & 40.63 & 41.19 & $40.42^{\mathrm{c}}$ & 1.21 \\
\hline 7.5 & 41.24 & 41.72 & 43.33 & 43.76 & $42.51^{\mathrm{b}}$ & \\
\hline 10 & 44.72 & 44.57 & 46.46 & 48.41 & $46.04^{\mathrm{a}}$ & \\
\hline Rata-rata & $39.99^{\mathrm{c}}$ & $40.98^{\mathrm{b}}$ & $41.94^{\mathrm{ab}}$ & $43.01^{\mathrm{a}}$ & & \\
\hline
\end{tabular}

Keterangan : Nilai rata-rata yang diikuti oleh huruf yang berbeda berarti berbeda nyata pada taraf $a=0,05$

\section{Jumlah Daun}

Tabel 2. Rata-rata jumlah daun tomat umur 49 HST

\begin{tabular}{cccccc}
\hline \multirow{2}{*}{$\begin{array}{c}\text { PupuK } \\
\text { Kascing (ton) }\end{array}$} & \multicolumn{3}{c}{ POC Lestari Green (cc/L) } & \multirow{2}{*}{ NP BNJ } \\
\cline { 2 - 4 } 0 & 0 & 5 & 10 & 15 & 0.05 \\
\cline { 2 - 4 } 5 & $14.00^{\mathrm{e}}$ & $14.37^{\mathrm{cd}}$ & $14.00^{\mathrm{e}}$ & $14.00^{\mathrm{e}}$ & \\
7.5 & $14.11^{\mathrm{d}}$ & $14.11^{\mathrm{d}}$ & $14.44^{\mathrm{cd}}$ & $14.26^{\mathrm{de}}$ & 0.30 \\
10 & $14.33^{\mathrm{cd}}$ & $14.44^{\mathrm{cd}}$ & $14.41^{\mathrm{cd}}$ & $14.48^{\mathrm{cd}}$ & \\
\hline
\end{tabular}

Keterangan : Nilai rata-rata yang diikuti oleh huruf yang berbeda berarti berbeda nyata pada taraf $a=0,05$ 


\section{Umur Berbunga}

Tabel 3. Rata-rata umur berbungga umur 32 HST

\begin{tabular}{|c|c|c|c|c|c|c|}
\hline \multirow{2}{*}{$\begin{array}{l}\text { Pupuk } \\
\text { Kascing (ton) }\end{array}$} & \multicolumn{4}{|c|}{ POC Lestari Green (cc/L) } & \multirow{2}{*}{ Rata-rata } & \multirow{2}{*}{$\begin{array}{c}\text { NP BNJ } \\
0.05\end{array}$} \\
\hline & 0 & 5 & 10 & 15 & & \\
\hline 0 & 33.67 & 32.67 & 32.78 & 32.89 & $33.00^{c}$ & \\
\hline 5 & 32.22 & 32.56 & 32.56 & 32.44 & $32.44^{\mathrm{bc}}$ & 0.50 \\
\hline 7.5 & 32.78 & 32.11 & 32.11 & 31.33 & $32.08^{b}$ & \\
\hline 10 & 32.00 & 31.44 & 31.00 & 30.11 & $31.14^{\mathrm{a}}$ & \\
\hline Rata-rata & $32.67^{\mathrm{b}}$ & $32.19^{\mathrm{b}}$ & $32.11^{\mathrm{ab}}$ & $31.69^{\mathrm{a}}$ & 32.17 & \\
\hline
\end{tabular}

\section{Cabang Produktif}

Tabel 4. Rata-rata cabang produktif pertanaman umur 90

\begin{tabular}{|c|c|c|c|c|c|c|}
\hline \multirow{2}{*}{$\begin{array}{c}\text { Pupuk } \\
\text { Kascing (Ton) }\end{array}$} & \multicolumn{4}{|c|}{ POC Lestari Green (cc/L) } & \multirow{2}{*}{ Rata-rata } & \multirow{2}{*}{$\begin{array}{c}\text { NP BNJ } \\
0.05\end{array}$} \\
\hline & 0 & 5 & 10 & 15 & & \\
\hline 0 & 1.76 & 1.93 & 2.02 & 1.98 & $1.92^{\mathrm{b}}$ & \multirow{4}{*}{0.09} \\
\hline 5 & 2.11 & 2.15 & 2.09 & 2.28 & $2.16^{\mathrm{b}}$ & \\
\hline 7.5 & 2.22 & 2.13 & 2.24 & 2.28 & $2.22^{\mathrm{ab}}$ & \\
\hline 10 & 2.28 & 2.26 & 2.28 & 2.39 & $2.30^{\mathrm{a}}$ & \\
\hline Rata-rata & $2.09^{\mathrm{ab}}$ & $2.12^{\mathrm{ab}}$ & $2.16^{\mathrm{ab}}$ & $2.23^{\mathrm{a}}$ & 2.15 & \\
\hline
\end{tabular}

\section{Jumlah Buah}

Tabel 5. Rata-rata jumlah buah pertanaman 6 kali penen

\begin{tabular}{|c|c|c|c|c|c|}
\hline \multirow{2}{*}{$\begin{array}{l}\text { Pupuk } \\
\text { Kascing(ton) }\end{array}$} & \multicolumn{4}{|c|}{ POC Lestari Green (cc/L) } & \multirow{2}{*}{$\begin{array}{l}\text { NP BNJ } \\
\quad(0.05)\end{array}$} \\
\hline & 0 & 5 & 10 & 15 & \\
\hline 0 & $24.83^{\mathrm{g}}$ & $29.69^{f}$ & $30.11^{\mathrm{e}}$ & $30.69^{e}$ & \\
\hline 5 & $30.64^{e}$ & $29.86^{\mathrm{f}}$ & $31 .{ }^{78 \mathrm{de}}$ & $32.92^{\mathrm{de}}$ & 1.40 \\
\hline 7.5 & $32.19^{\text {de }}$ & $32.31^{\mathrm{de}}$ & $33.83^{\mathrm{d}}$ & $35.75^{\mathrm{cd}}$ & \\
\hline 10 & $37.33^{\mathrm{b}}$ & $36.28^{c}$ & $37.72^{\mathrm{b}}$ & $44.08^{\mathrm{a}}$ & \\
\hline
\end{tabular}

Keterangan : Nilai rata-rata yang diikuti oleh huruf yang berbeda berarti berbeda nyata pada taraf $a=0,05$ 


\section{Berat Buah}

Tabel 6. Rata-rata berat buah pertanaman (6 kali panen)

\begin{tabular}{ccccccc}
\hline \multirow{2}{*}{$\begin{array}{c}\text { Pupuk } \\
\text { Kascing (ton) }\end{array}$} & \multicolumn{3}{c}{ POC Lestari Green (cc/L) } & & NP BNJ \\
\cline { 2 - 5 } 0 & 0 & 5 & 10 & 15 & & 0.05 \\
5 & 0.83 & 1.03 & 1.17 & 1.05 & $1.02^{\mathrm{c}}$ & \\
7.5 & 1.09 & 1.19 & 1.16 & 1.22 & $1.17^{\mathrm{b}}$ & 0.10 \\
10 & 1.15 & 1.14 & 1.27 & 1.31 & $1.22^{\mathrm{b}}$ & \\
\hline Rata-rata & 1.44 & 1.37 & 1.41 & 1.65 & $1.47^{\mathrm{a}}$ & \\
\hline
\end{tabular}

Keterangan : Nilai rata-rata yang diikuti oleh huruf yang berbeda berarti berbeda nyata pada taraf $a=0,05$

\section{Diameter Buah}

Gambar 2. Rata-rata diameter buah $(\mathrm{cm})$ pada berbagai takaran pupuk organik kascing dan konsentrasi pupuk organik cair Lestari Green

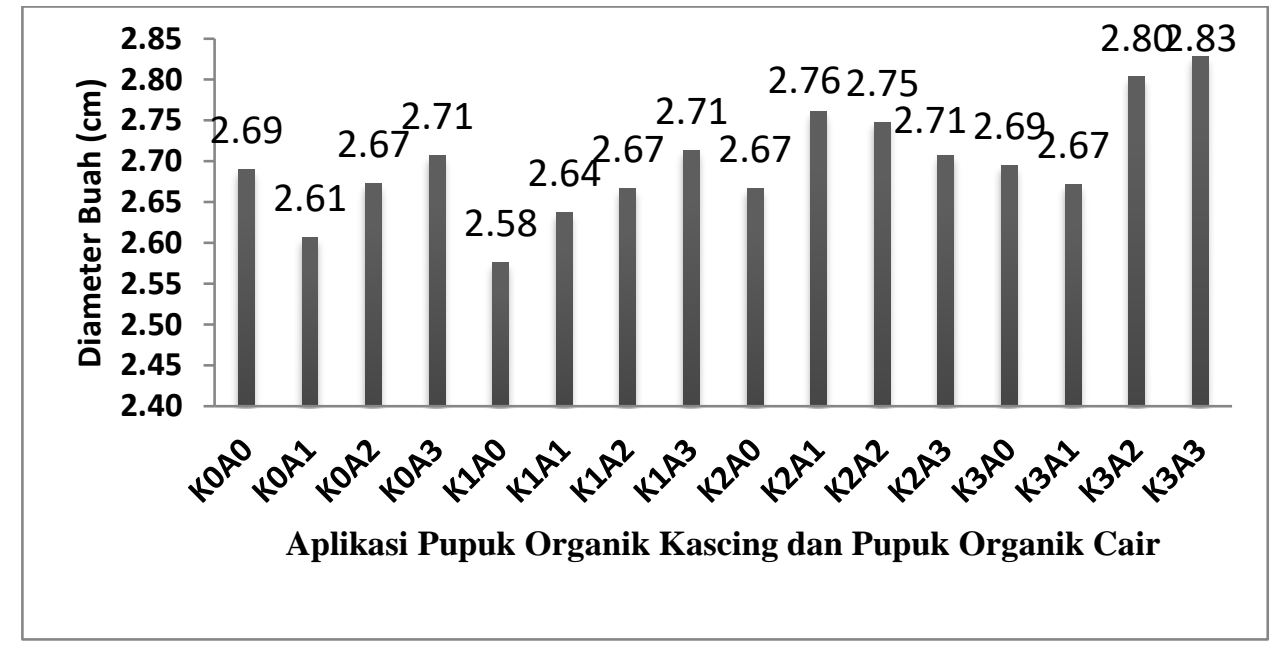

\section{Produksi Buah per petak}

Tabel 7. Rata-rata produksi buah/petak (kg) 6 kali panen

\begin{tabular}{|c|c|c|c|c|c|c|}
\hline \multirow{2}{*}{$\begin{array}{l}\text { Pupuk } \\
\text { Kascing (ton) }\end{array}$} & \multicolumn{4}{|c|}{ POC Lestari Green (cc/L) } & \multirow{2}{*}{ Rata-rata } & \multirow{2}{*}{$\begin{array}{r}\text { NP BNJ } \\
0.05\end{array}$} \\
\hline & 0 & 5 & 10 & 15 & & \\
\hline 0 & 3.04 & 3.79 & 4.28 & 3.84 & $3.74^{\mathrm{d}}$ & \\
\hline 5 & 4.00 & 4.35 & 4.26 & 4.48 & $4.27^{\mathrm{c}}$ & \\
\hline 7.5 & 4.23 & 4.17 & 4.64 & 4.79 & $4.46^{\mathrm{b}}$ & 0.36 \\
\hline 10 & 5.29 & 5.03 & 5.18 & 6.03 & $5.38^{\mathrm{a}}$ & \\
\hline Rata-rata & $4.14^{\mathrm{b}}$ & $4.34^{\mathrm{b}}$ & $4.59^{\mathrm{ab}}$ & $4.78^{\mathrm{a}}$ & & \\
\hline
\end{tabular}





\section{Produksi Buah per Hektar}

Tabel 8. Rata-rata produksi buah/ha (ton)

\begin{tabular}{|c|c|c|c|c|c|c|}
\hline \multirow{2}{*}{$\begin{array}{l}\text { Pupuk } \\
\text { Kascing (ton) }\end{array}$} & \multicolumn{4}{|c|}{ POC Lestari Green (cc/L) } & \multirow{2}{*}{ Rata-rata } & \multirow{2}{*}{$\begin{array}{r}\text { NP BNJ } \\
0.05\end{array}$} \\
\hline & 0 & 5 & 10 & 15 & & \\
\hline 0 & 20.27 & 25.26 & 25.43 & 25.58 & $24.13^{\mathrm{d}}$ & \\
\hline 5 & 26.64 & 29.03 & 28.41 & 29.84 & $28.48^{c}$ & \\
\hline 7.5 & 28.17 & 27.82 & 30.93 & 31.93 & $29.71^{\mathrm{b}}$ & 2.52 \\
\hline 10 & 35.24 & 33.53 & 34.53 & 40.23 & $35.88^{\mathrm{a}}$ & \\
\hline Rata-rata & 27.58 & 28.91 & 29.82 & 31.89 & & \\
\hline
\end{tabular}

Keterangan : Nilai rata-rata yang diikuti oleh huruf yang berbeda berarti berbeda nyata pada taraf $a=0,05$

1. Pengaruh Pupuk Organik Kascing dapat memperbaiki sifat fisik, kimia dan Terhadap Pertumbuhan dan Produksi Tomat

Aplikasi pupuk organik kascing memperlihatkan pengaruh yang sangat nyata terhadap komponen pengamatan pertumbuhan dan produksi tanaman tomat yaitu, tinggi tanaman, jumlah daun, umur berbunga, jumlah buah, cabang produktif, berat buah dan produksi buah/ha. Hal ini memperlihatkan bahwa pada takaran pupuk organik kascing 10 ton/ha $(1,500 \mathrm{~kg} /$ petak $)$ memberikan pengaruh terbaik ketimbang dengan tanpa perlakuan pupuk organik kascing tinggi tanaman rata-rata $46.04 \mathrm{~cm}$. Hal ini dikarenakan bahwa adanya unsur hara dan senyawa-senyawa organik yang terdapat dalam pupuk organik kascing tersebut sehingga dapat memacu pertumbuhan vegetatif tanaman dan biologi tanah. Mulat, 2003 mengatakan bahwa kascing dapat memperbaiki sifat biologi tanah karena kascing mengandung banyak mikroba dan hormon perangsang pertumbuhan tanaman, seperti giberilin, sitokinin dan auksin dan jumlah mikroba yang banyak dan aktivitasya yang tinggi biasa mempercepat mineralisasi atau pelepasan unsur hara dari kotoran cacing menjadi bentuk tersedia bagi tanaman.

Pupuk organik kascing yang diberikan terhadap tanaman tomat memberikan respon yang baik terhadap pertumbuhan generatif yaitu umur berbunga, jumlah buah, diameter buah, berat buah dan produksinya sebab tanaman tomat menyerap unsur hara makro dan mikro dari dalam tanah. Karena pupuk kascing mengandung (N) 
0.63\%, fosfor(P) $0.35 \%$, kalium (K) $0.2 \%$, kalsium (Ca) $0.23 \%$, mangan (Mn) 0.003\%, magnesium (Mg) $0.26 \%$, tembaga $(\mathrm{Cu}) 17,58 \%$, seng $(\mathrm{Zn}) 0.007 \%$, besi (Fe) 0.79\%, molibdenum (Mo) $14.48 \%$, bahan organik $0.21 \%$, KTK 35.80 me\%, kapasitas menyimpan air $41.23 \%$ dan asam humat $13.88 \%$ (Mulat, 2003). Pemberian kascing pada tanah dapat memperbaiki sifat tanah seperti memperbaiki struktur, porositas, permeabilitas, meningkatkan kemampuan untuk menahan air. Disamping itu kascing dapat memperbaiki sifat kimia tanah seperti meningkatkan kemampuan untuk menyerap kation sebagai sumber hara makro dan mikro serta meningkatkan $\mathrm{pH}$ pada tanah asam. Pemakaian kascing diharapkan mampu mengurangi penggunaan pupuk kimia dan meningkatkan penggunaan pupuk organik sehingga mengurangi pencemaran lingkungan (Luh, 2005). Pupuk kascing 10 ton/ha dapat memberikan pengaruh terbaik terhadap pertumbuhan dan produksi tanaman tomat karena semakin tinggi dosis yang diberikan ke dalam tanah dapat meningkatkan kapasitas tukar kation, siklus hara sehingga hasil dari kotoran cacing tersebut menjadi bentuk yang dapat tersedia bagi tanaman (Mulat, 2003; Agus wahyudi dkk., 2006).

\section{Pengaruh Pupuk Organik Cair Lestari Green Terhadap Pertumbuhan dan Produksi Tomat}

Pupuk organik cair Lestari Green memperlihatkan pengaruh yang sangat nyata terhadap komponen pengamatan pertumbuhan dan produksi tanaman tomat yaitu tinggi tanaman, jumlah daun, jumlah buah, cabang produktif, berat buah dan produksi buah/ha. Perlakuan pupuk cair organik meningkatkan semua komponen peubah tanaman. Hal ini diduga bahwa kandungan POC Lestari Green yang berupa unsur hara makro dan mikro. Kandungan pupuk Lestari Green yaitu N $(5,25 \%)$, P2O5 (2,12\%), K2O (7,94\%), Carbon Organik $(5,17 \%), \mathrm{SO} 4(3,67 \% 0$, Solid Content (16,52\%), Ca (2,25\%), Mg $(0,20 \%)$, Chlorida (1,68\%), pH(6,7). Hal ini juga terjadi karena pupuk organik cair tersebut diaplikasikan melaui daun, sehingga memudahkan tanaman menyerap unsur hara yang diberikan melalui mulut daun (stomata) dan celah-celah kutikula. Hal ini sesuai dengan Sutanto (2002) yang menyatakan bahwa pupuk yang diberikan lewat daun diharapkan dapat diserap melalui mulut daun (stomata) dan celahcelah kutikula, sehingga lebih cepat 
tersedia dan digunakan oleh tanaman untuk kebutuhan pertumbuhannya. Dan beberapa hasil penelitian menunjukkan bahwa pemberian pupuk organik cair melalui daun memberikan pertumbuhan dan hasil tanaman yang lebih baik daripada melalui tanah. Penggunaan konsentrasi pupuk organik cair yang tepat dapat memperbaiki pertumbuhan, mempercepat panen, memperpanjang masa atau umur produksi dapat meningkatkan hasil tanaman (Rizqiani,et,al. 2007).

Dalam hal ini sesuai dengan hasil penelitian (Tri Harmoni Abadi. 2007) pemberian pupuk organik cair pada dosis $15 \mathrm{cc} / \mathrm{L}$ dapat meningkatkan produksi panen 40\%-100\%, mencegah atau mengurangi gugur bunga dan buah, memperkuat jaringan pada akar dan batang, sebagai katalisator sehingga dapat mengurangi penggunaan pupuk dasar sampai $50 \%$, meningkatkan daya tahan tanaman terhadap serangan penyakit terutama fungi atau cendawan, mempercepat panen pada tanaman semusim.

Hasil penelitian diketahui bahwa konsentrasi POC yang terbaik untuk meningkatkan komponen parameter tinggi tanaman, jumlah daun, umur berbunga, cabang produktif, jumlah buah, berat buah, produksi buah per hektar dan umur berbunga adalah konsentrasi $15 \mathrm{cc} / \mathrm{L}$ air. Hal ini disebabkan karena pupuk cair mengandung unsur hara makro dan mikro yang lengkap serta dapat dapat diaplikasikan ke tanaman dengan tepat sesuai dengan kebutuhannya. Hal ini sesuai dengan pernyataan Lingga dan Marsono (2007), menyatakan bahwa tanaman tidak cukup hanya mengandalkan unsur hara dari dalam tanah saja. Oleh karena itu, tanaman perlu diberi unsur hara tambahan dari luar, yaitu berupa pupuk. Upaya peningkatan efisiensi penggunaan pupuk dapat ditempuh melalui prinsip tepat jenis, tepat dosis, tepat cara, tepat waktu aplikasi, dan berimbang sesuai kebutuhan tanaman.

\section{Interaksi Antara Pemberian Pupuk Kascing dan Pupuk Organik Cair Terhadap Pertumbuhan dan Produksi Tanaman Tomat.}

Aplikasi pupuk kascing dengan POC Lestari Green berpengaruh sangat nyata terhadap jumlah daun. Terdapat peningkatan jumlah daun akibat adanya interaksi antara pupuk organik kascing dan POC Lestrari Green diduga karena pemberian pupuk kascing dapat meningkatkan bahan organik pada media 

tanam, yang penting dalam menyediakan hara makro dan mikro, meningkatkan kapasitas tukar kation (KTK) tanah serta dapat bereaksi dengan ion logam untuk membentuk senyawa. Hal ini sesuai dengan pernyataan Setyorini (2005) yang menyatakan bahwa bahan organik penting dalam menyediakan hara makro dan mikro seperti $\mathrm{Zn}, \mathrm{Cu}, \mathrm{Mo}, \mathrm{Co}, \mathrm{Ca}, \mathrm{Mg}$, dan $\mathrm{Si}$ meningkatkan kapasitas tukar kation (KTK) tanah serta dapat bereaksi dengan ion logam untuk membentuk senyawa kompleks, sehingga ion logam yang meracuni tanaman atau menghambat penyediaan hara $\mathrm{Al}, \mathrm{Fe}$ dan $\mathrm{Mn}$ dapat dikurangi. Peningkatan jumlah daun tersebut disebabkan karena takaran pupuk organik kascing dan konsentrasi pupuk organik cair tersebut yang diberikan sudah tepat.

Kombinasi terbaik terdapat pada kascing 10/ha dengan POC Lestari Green 15 cc/l air/petak. Rosmarkan dan Yuwono (2002) menyatakan bahwa dalam pertumbuhan dan perkembangan tanaman selain unsur hara makro, tanaman juga memerlukan unsur mikro meskipun dalam jumlah yang kecil. Unsur hara mikro yang dibutuhkan meliputi Fe (Besi), B (Boron), Mo (Molibdenum), $\mathrm{Cu}$ (Temabaga), $\mathrm{Zn}$ (Seng), Mn (Mangan) dan $\mathrm{Cl}$ (Chlor).
Sutedjo (2002) juga mengatakan bahwa tidak lengkapnya unsur hara makro dan unsur hara mirko dapat mengakibatkan hambatan bagi pertumbuhan dan perkembangan tanaman serta berpengaruh langsung terhadap produktifitas tanaman. Ketidaklengkapan salah satu atau beberapa dari unsur hara makro dan mikro dapat diatasi dengan pemupukan berimbang baik menggunakan pupuk organik maupun pupuk anorganik.

\section{KESIMPULAN}

Berdasarkan hasil percobaan diperoleh kesimpulan sebagai berikut:

1. Penggunaan pupuk organik kascing dengan takaran 10 ton/ha memberikan pengaruh terbaik rata-rata tinggi tanaman baik yaitu $46,04 \mathrm{~cm}$, umur berbunga tercepat yakni 31,14 hari, cabang produktif sebanyak 2,30 , berat buah $1,47 \mathrm{~kg}$ pertanaman, produksi buah per petak sebanyak $5,38 \mathrm{~kg}$ dan produksi buah/hektar sebanyak 35,88 ton

2. Penggunaan POC Lestari Green dengan konsentrasi $15 \mathrm{cc} / \mathrm{L}$ air memberikan pengaruh terbaik pada rata-rata tinggi tanaman yaitu $43,01 \mathrm{~cm}$, umur berbunga tercepat yakni 31,69 hari, cabang produktif sebanyak 2,23, berat buah sebanyak $1,30 \quad \mathrm{~kg}$ 

pertanaman produksi buah per petak sebanyak 4,78 kg.

3. Kombinasi perlakuan takaran pupuk organik kascing dan konsentrasi pupuk organik cair Lestari Green yang dapat memperbaiki pertumbuhan dan meningkatkan produksi tanaman tomat adalah pupuk organik kascing 10 ton/hektar dan POC Lestari Green konsentrasi $15 \mathrm{cc} / \mathrm{L}$ air pada parameter Jumlah daun dan jumlah buah.

\section{Saran}

Untuk meningkatkan pertumbuhan dan produksi tanaman tomat dianjurkan menggunakan pupuk organik kascing dengan takaran 10 ton/ha dan POC (LestariGreen) $15 \mathrm{cc} / \mathrm{L}$ atau 9,9 L/ha.

\section{DAFTAR PUSTAKA}

Adisarwanto. 2013. Manfaat Penggunaan pupuk organik untuk kesuburan tanah. Universitas Tulungagung Bonorowo. Diakses 2 agustus 2017

BPS Sulawesi Selatan. 2011. Kabupaten Luwu Timur Dalam Angka. Bappeda Kabupaten Luwu Timur. Malili.

Buckman, O.H dan N.C Brady, 1969.The Nature and Properties of soils.Edisi terjemahan Soegiman.1982. Ilmu Tanah. Bhratara Karya Angkasa. Jakarta.
Haryanto, B. 2007. Cara Praktis Membuat Kompos. Agro Media Pustaka. Jakarta.

Kariada, I.K. dan Aribawa I.B. 2009. Kajian Penerapan Pupuk Organik dalam Mendukung Pengelolaan Tanaman Terpadu (PTT) di Subak Mangku Tahanan, Bali.Balai Besar Penelitian dan pengembangan Sumberdaya Lahan Pertanian. Bogor.

Mulat, T. 2003. Membuat dan Memanfaatkan Kascing Pupuk Organik Berkualitas. Agromedia Pustaka, Jakarta.

Rosmarkam dan Yuwono (2006). Pupuk Organik Tingkatkan Produksi Pertanian.

http://litbang.deptan.go.id.idpublika siwr276057.pdf. Diakses 18 November 2016.

Rizqiani et.al.( 2007) budidaya Tomat $<$ http://tani blog.fisip.uns.ac.id. Diakses pada tanggal 15 juni 2017.

Rizqiani.N.F. 2007.Pengaruh Dosis dan Frekuensi Pemberian Pupuk Organik Cair Teradap Pertumbuhan Hasil Tanaman uncis. Universitas Gaja Mada. Jogjakarta. Jurnal Ilmu Tana dan Lingkungan Vol 7 No.1 (2007) Hal.43-53.

Sastrahidayat, R.I. 2000. Peranan Keanekaragaman Hayati dalam Sistem Pertanian Organik dan Pengendalian Hama-Penyakit. (Tesis). Fakultas Pertanian. Unibraw. Malang. 

Nurhaeni Sanda : Efektivitas Penggunaan Pupuk Organik Kascing dan Pupuk Organik Cair pada Pertumbuhan dan Produksi Tanaman Tomat (Lycopersicum esculantum Mill)

Sinamora, S. dan Salundik. 2006.

Meningkatkan Kualitas Kompos.

Agro Media Pustaka. Jakarta. 